\title{
Study of the Open Structure in Oracle Night as a Metafiction
}

\author{
Hui Ni \\ Department of English, Heze University, Heze 274000, Shandong, China \\ Email: melody1014@163.com
}

\begin{abstract}
Paul Auster is one of America's most inventive and original postmodernist writers, whose novels have received worldwide popularity. His new piece Oracle Night was written in 2003 when the literary postmodernism has become a prominent literary tendency and when metafiction has been a typically postmodernist writing model. This thesis aims to study metafictional structural features of Paul Auster's Oracle Night, which has not been given due critical attention to both in China and in foreign countries. Based on detailed textual analysis, the study contends that Oracle Night holds the structural features as a metafiction by attempting to explore the representative one, namely, the Open Structure exploited in this novel. According to the thesis, Auster violates normal narrative standards and creates a metafictional structure by subverting the "closed" structure into an Open Structure, which altogether accomplishes one of the fundamental features of metafictional writing.
\end{abstract}

Index Terms - Paul Auster, metafiction, open beginning, open ending, plots

\section{INTRODUCTION}

Often regarded as a postmodernist writer, a default classification due to his experimental techniques and ironic posturing, Paul Auster (1947- ) is noted for his idiosyncratic work, which resists simple categorization. His experimentation in writing techniques such as the handling of narrative point of view, and the controlling of narrative time, multilayer narratives, as well as metafictionality, but he is still not widely known, especially to Chinese people. Till now, many accolades have been given to this thriving writer, such as 1989 Prix France Culture de Littérature Étrangère, 1990 Morton Dauwen Zabel Award from the American Academy and Institute of Arts and Letters, 1996 John William Corrington Award for Literary Excellence, 2006 Prince of Asturias Award for Literature and so on.

The present thesis takes metafictional structural uniqueness as the research topic, so the theoretical background of the research and a literature review on Oracle Night are essential and fundamental to be offered in the first place.

Metafiction is a mode of writing within a broader cultural movement often referred to as postmodernism. As Patricia Waugh puts it,

"Metafiction is a term given to fictional writing which self-consciously and systematically draws attention to its status as an artifact in order to pose questions about the relationship between fiction and reality. In providing a critique of their own methods of construction, such writings not only examine the fundamental structures of narrative fiction, they also explore the possible fictionality of the world outside the literary fictional text." (Waugh, 1984, p. 2).

And several Chinese critics have also generalized some features of metafictional narration from different perspectives. ${ }^{1}$ To sum up, metafiction covers the following six major characteristics: juxtaposition of narrative and commentary discourses, open form, parody, fragmented collage, blurring of reality and fiction, random sequences of time and place. ${ }^{2}$ These elements provide the reader with various perspectives through which the reader is able to better read and appreciate metafictional narratives.

Literally, structure refers to either the way in which something is put together and organized or the framework or essential parts of a building (Zhang, 2006). On the part of the author of compositions, structure means the order of what they have written. According to McKee, "Structure is the order in which the novel presents the plot, a selection of events from characters life stories that is composed into a strategic sequence to arouse specific emotions and to express a specific view of life." (McKee, 1997, p. 33). In regard to literary works, structure generally means the shape of a single text, be it novel or poem. It has become a consensus among writers that good writers should have an overall design for the work before they start writing. It is emphasized to be the hidden spine on which the piece of writing is supported.

If we sum up the characteristics of metafiction from the aspect of the structure, we can conclude them as follows. Metafictionalists doubt any kind of continuity, asserting that the "closed" form of writing constructed by the coherence of meaning, the continuity of characters' actions and the coherence of plots in traditional writing must be broken down

$1 \mathrm{Hu}$ Quansheng, British and American Postmodernist Fiction: Reseach into Narrative Structure (Shanghai: Fudan University Publishing House, 2002, pp.30-41.

Tong Yanping, “On Metafiction,” Foreign Literature Review 3, 1994, pp.13-19.

2 Gan wenping, “On Robert Stone and Tim O’Brien: American Fiction of the Vietnam War within and beyond”, Xiamen: Xiamen UP, 2003 , p110. 
so as to shape a kind of writing of being open. Metafiction is a kind of non-linear novel which can be read in some different orders other than from beginning to end; most metafictional writings defy the closed ending and gift open endings or indeterminate endings, just as Conrad says of Henry James, "satisfying but not final...we get the multiple ending, the false ending, the mock ending or parody ending." (Lodge, 1977, p. 226) Oracle Night ends with the destiny and identity of the protagonist unsolved, which puts the whole novel in openness. By challenging the closed ending of classical realism as well as rejecting totalized, single, and determined narratives, the novel advocates the openness and pluralism of metafictional writing.

Since first being published in the US, Oracle Night has become popular as a best-seller. The author of the thesis finds that major issues which have already been studied concerning this novel mainly center on the postmodernist features, themes in the novel and the experimental narrative style.

From the above analysis which will be conducted in more extended form in the following chapters, it begins with supposition that Oracle Night is a metafiction. As Kate Liu ${ }^{3}$ states, "Contemporary author Paul Auster has made metafiction the central focus of his writing and is probably the best known active novelist specializing in the genre." And Oracle Night holds the essentiality to be analyzed more elaborately as a metafiction.

The author of traditional fiction often brings the characters and the reader totally under his control. What the reader has to do is to set him a goal of understanding what the author wants to express. However, metafiction varies from traditional fiction in that "The author of metafiction often invites the reader to participate in and make comments on his novels, thus constructing a new relationship between author, text and reader" (Gan, 2003, p. 114). In order to represent the disintegrated world full of contradictions in his eyes, Auster creates an open and pluralistic world in his novels.

Aristotle demands that the story does not start anywhere: well constructed stories would neither begin nor end at any chance point. However, Aristotelian logic and reasoning cannot be applied to the disjointed metafiction of Auster.

Open structure indicates that plots and the narrative structure have the following properties, namely, uncertainty, disconnection, chanciness and arbitrariness. (Lodge, 1988) No integrated and close-related plot or definite ending exist there. Also, narrative time is not limited to one style. The whole novel appears to be in an open, arbitrary and fragmented art form.

Auster's stories in Oracle Night branch out in all directions, without a beginning, middle or end like some structureless "rhizome." It reflects typically postmodern central emptiness under the absent god (Žižek, 1995). Absence of the ultimate divine truth, like the absence of an organizing center or a frame, gives way to pagan proliferation of the meaning of the text. As a writer of metafiction which exists alone "with no before or after," (Barone, 1995, p. 86) Auster disrupts the linear progression of the story and relies on chance to move the plot forward. Thus, complexity opposes earlier linear continuity of cause and effect.

\section{OPEN BEGINNING AND ENDING}

Beginning is an issue that belongs to the category of literary structure, and a heated issue among literary critics. As early as the period of ancient Greece, Plato states that any literary work is "an organic whole" and that every work contains its compulsory parts, i.e. the beginning, the middle and the end.

Then, Aristotle again claims in his Poetic:

Now a whole is that which has a beginning, a middle, and an end. A beginning is that which does not necessarily come after something else, although something else exists or comes after it. And end, on the contrary, is that which naturally follows something else either as a necessary or as a usual consequence, and is not itself followed by anything." (Aristotle, 2007, p. 28)

This concept has been obeyed as a convention. Traditional fiction always puts its trust in the synthesized order of beginnings and endings, while postmodernist fiction feels free to dispense with these arbitrary conventions.

As J. Hillis Miller (1998) indicates in Reading Narrative, "there is no such thing as beginning in narrative literature." (p. 103) A beginning exists only in condition that some events happen at present or beforehand, which lay a foundation for the development of the story. Again the events happening beforehand should still have events ahead. Thuswise, we may find that there is no real beginning in this kind of writing. And the links between different plots become looser and looser, so open structure is infused into the novel, scattered among the plots and lines of the novel.

From which point does the author start the story? How does the author begin the narration? And what is the point of starting the story like this? The very beginning of Oracle Night suggests the answer.

I had been sick for a long time. When the day came for me to leave the hospital, I barely knew how to walk anymore, could barely remember who I was supposed to be. Make an effort, the doctor said, and in three or four months you'll be back in the swing of things. I didn't believe him, but I followed his advice anyway. They had given me up for dead, and now that I had confounded their predictions and mysteriously failed to die, what choice did I have but to live as though a future life were waiting for me? (Oracle Night 1)

Oracle Night begins casually for no apparent reason. Readers are confused to ask such questions as what is the relationship between his illness and things coming next. The opening paragraph indicates two possibilities for Sidney.

3 Kate Liu, Associate Professor, English Department of Fu Jen Catholic University, Taiwan.

4 Deleuze, Guattari and A.Philips Griffiths (ed.), Concept as Mentioned in Contemporary French Philosophy, 1987, p. 134. 
One is that he is very likely to recover from the fatal disease, and regains everything, including his talent in writing; the other one is that though he regains his life, he becomes a handicapped man with no desire to write. Using the opening paragraph, Auster drops a hint to the readers that postmodern life is full of chanciness and uncertainty.

What is more, Auster deliberately designs a circular structure. Near the end of the novel, "I" again walk in and out of the hospital, which is also what "I" do at the beginning of the novel. So without coincidences, there would be no stories. Moreover, like most postmodernist writers, the novelist begins with an absurd opening plot and a stunning description, because of which readers take up the novel with an invincible motive without any historical background. In Oracle Night, the novelist does not tell the readers why "I" fall ill, what kind of illness "I" have, why "I" should buy the blue notebook, and what forces "me" to write unconsciously on the notebook or even to lose "myself" in the writing. So, all these interrogations running through the whole novel do not work as the beginning. The "free I" open the book and yet do not begin the story or the writing process that the novel delineates. "What choice did I have but to live as though a future life were waiting for me?" (p. 1) is a sign to express Sidney's feeling about the somber future. This expression will induce readers to do the further reading and has left much space for the development of plots.

Therefore, because of the indefinite beginning, the commonly expected story with complete and definite theme becomes doubtful. Along with the reading, we may find that Sidney's recovery from illness and his future life with others is not the centre of Oracle Night, but only functions as a framework onto which other stories will hang. To a certain extent, it only works as an excuse to keep the narration going. In order to live over again, he takes up his old trade as a writer to start with a story about Bowen. In the story, he models characters based on the personalities, professions and appearances of his acquaintances. And some made stories in Oracle Night also begin unexpectedly, which can hardly make up an organic whole. Oracle Night stretches in several directions and quite a few stories within are overlapping. The finding of an old-fashioned plotline in this novel seems impossible; as a result, it is impossible to pinpoint a definite ending of the text.

The openness of metafiction also means that there is no definite ending about a character's story. Or, different characters have different story versions concerning the same person. All of the versions are equally possible and acceptable. A traditional text is often characterized by order and organization of beginning, middle, and end. Despite its complication, the plot is mostly organized in such a way that it leads to a proper ending. The narrative movement always ends with a closure. "Endings", the "exits" of fictions, are particularly significant in this connection. We can say that it emphasizes the continuity of meaning, character's behavior and the continuity of plots, which can be regarded as writing in closed form.

Instead of the closed ending of the traditional novel in which mystery is explained and fortunes are settled, and instead of the open ending of the modernist novel, "satisfying but not final" as Conrad says of Henry James, "we get the multiple ending, the false ending, the mock ending or parody ending." A fictional piece may have no ending at all, or circle back to its own beginning. As a story-telling technique, open endings are unsatisfying for most readers in that the pay-off of the novel's conflict never arrives. Authors appreciate this technique just because they doubt there is a real possibility of a solution to the problem and conflict they have just explored. They take the risk of using them because they believe strongly that this is how they must end the novel. We may feel that "A moment before we expect the climax in the obligatory scene to happen, the novel is just over" (Delaney, 1958, p. 27). Oracle Night, by challenging the closed ending and rejecting those totalized, single, and determined narratives, advocates the openness and pluralism of metafictional writing.

In Oracle Night, there are several open endings, for the novel is multilayered. First, we should look at the end of the major story, that is, the story of the narrator, Sidney Orr, and his composing process and the relationship with his wife, John Trause and Jacob, and so on.

In Chapter 8, in Sidney Orr's story about Bowen's fatal destiny, Orr says:

......with no other option available to him, Bowen settles in to wait out his solitary confinement, hoping to discover enough patience and fortitude to bear up to his absurd predicament [...] the bulb in the overhead light burns out, and Nick finds himself sitting alone in the darkness, staring at the glowing orange coils of the electric heater. (p. 94)

Here, the author indicates that Bowen's life is definitely trapped into a dead end. However, the author does not mean to create a story like this. So in Chapter 18, Orr writes that "Bowen would be trapped in the room forever, and I decided that the moment had finally come to abandon my efforts to rescue him." (p. 96) This sentence suggests that the author is not to create a fatal destiny for Bowen, but as the writing process goes on, the author has no other choice. Still, other possibilities may take place: what if Edward would come back to his sense. There would be another ending for Bowen's destiny.

Another example for an open ending is found through the analysis of the main story line, that is, the development of the Sidney Orr's fate. Several months into his recovery from a near-fatal illness, Sidney Orr enters a stationery shop in the Cobble Hill section of Brooklyn and buys a blue notebook. It is September 18, 1982, and for the next nine days Orr will live under the spell of this blank book, trapped in a world of eerie premonitions and bewildering events that threaten to destroy his marriage and undermine his faith in reality. In Oracle Night, the reader may figure out many possible endings for Sidney Orr. Auster leaves us many possibilities of the relevant person in the novel; for example, we never know who the father of the aborted fetus is and we have no idea about the future of Orr and his wife. In short, the answer is uncertain and open for the good and proper. 
In summary, each time one story ends, another story starts or has started to take over the torch. Such never-ending pattern just reflects the main feature of the 20th century daily life. No matter what happens, life has yet to go on, notwithstanding accompanied with hurts, deceits or even deaths.

\section{OPEn LinKS AMONG Plots}

Authors of metafiction are opposed to close structure, the logicality and continuity of traditional plots which, in their opinion, are not based on the common daily life. So what they should do is to break the closed structure of plots and replace it with the Open Structure of plots. In the composing process, they often "violate the narrative levels by intruding into the narration to comment on the writing process or involving him or herself with fictional characters" (Stuart, 2005, p.117). They also reverse the time of the past, the present and the future at their will. By changing the time order, they break up the realistic and physical space and create a novel with various plots in an arbitrary and psychological way. In this regard, we can name it Open Structure of plots.

A middle is that which follows something else, and is itself followed by something. Thus well-constructed plots must neither begin nor end in a haphazard way, but must conform to the pattern I have been describing. (Aristotle, 2007)

Component elements ought to be so firmly compacted that if any one of them is shifted to another place and removed, the whole is loosened up and dislocated. (Aristotle, 2007)

But for metafiction, or Oracle Night more specifically, plots are not arranged in a "well-constructed" way as Aristotle proposes. They do not develop from one plot to the next in a causal relation. The aim of the novel is not to bring the reader from one point to the next in a logical way. On the contrary, the author often breaks up or ceases the continuity of the developing plot in some ways, such as the insertion of paragraph of comment or stream-of-consciousness; describing another story that is logically irrelevant to the previous story both in time and spatial order. William G. Little states that "Auster's stories are not plotless but the plots are constantly foiled." "In a story in which nothing happens, waiting for some sign or a message is equally futile, like Waiting for Godot." In the meantime, events have become increasingly obscure, characters drop off the pages without explanation, but meaning proliferates from the process.

In Oracle Night, the creator often subverts the continuity of the spatio-temporal sequence and forms a sense of trans-placement. He replaces the orders of the stories which happen at different time and links the stories under the notion of Open Structure. Open links are presented at three different aspects. In the first place, judging from the links of different chapters, we can easily find that different chapters are not closely connected. The first six chapters are narratives about Sidney Orr, his social relationships with other people and his writing process about a new story on Bowen. Chapter 7 and Chapter 8 are about story contents on Bowen. And the following chapters are again about some events about Sidney Orr. Some chapters start without any clue about why it will be arranged in that order. Different chapters often start like this "next morning", "back to last Wednesday", "I slept late the next morning", and the like. From the above examples, we may know that each chapter can be rearranged, that is, the latter chapter can be arranged beforehand, and the former chapter can also be arranged afterward. So the links of order among different chapters can be considered as open. In the second place, the links between different stories also appear to be open. As the present thesis puts forward, Oracle Night consists of many stories, some of which are closely related to its body, while others are about its background information, still some others are not so closely connected to the theme of the whole novel. In this respect, we can say that some stories can be rearranged as the writer likes. For example, in Chapter 9, Auster inserts a news report with the title "BORN IN A TOILET, BABY DISCARDED," which has not so much relationship with the main stream of the narration. In Chapter 10, "The Time Machine" and the story thereafter are also other stories of the similar effect. Besides, stories in the footnotes work as complementary contents to the whole. Analysis of the novel elucidates that there are a series of mysteries in the novel which Auster does not make clear at all. This invites the reader onto a journey of seeking for and finding out the clues. In the third place, the narrator intentionally exposes him as the author of the story between whiles. Thereby, the links of stories would appear to be open for the intrusiveness of narrators. The narrator, Sidney Orr claims for several times in the novel that he is the author of the story. And the clues are as follows.

At the beginning of this novel, he says:

I hadn't written anything since coming home from hospital in May—not a sentence, not a word—and hadn't felt the slightest inclination to do so. Now, after four months of apathy and silence, I suddenly got it into my head to stock up on a fresh set of supplies $[\ldots]$ (p. 3)

From this short narration, we can learn about Sidney Orr that he is a writer who has dropped writing for a relatively long period and that he wants to resume his old profession as a writer. We would unavoidably think that he would compose some pieces of fiction or other forms of writing.

As we expect, the creation process begins from the paragraph below:

I sat at my desk for the first time in almost nine months, staring at my newly acquired notebook and struggling to come up with an opening sentence that wouldn't embarrass me or rob me of my courage, I decided to give the old Flitcraft episode a shot [...] so I removed the cap from my pen, pressed the point against the top line of the first page in the blue notebook, and started to write. (p. 13)

5 “Contemporary Literature”, Spring 1997, Vol 38, No1 
And still after the composing intention, he begins to create the story about Nick Bowen, in which he moulds characters following the example of Hammett's prototype. On the one hand, he continues the creation of Bowen; on the other hand, he takes his acquaintances as the main source. Meanwhile, he does not forget to tell readers that he is composing stories after nine months of fatal disease. Obviously, this narration interrupts the continuity of the novel creation, which is a transparent presentation of open plots.

He puts it like this:

$\mathrm{He}$ is necessarily good at his job, admired by his colleagues, financially secure, happy in his marriage, and so on. Or so it would appear to a casual observer, but as my version of the story begins, trouble has been stirring in Bowen for some time $[\ldots]$ (p. 13)

On Page 32, the narrator again states his intention of writing "that's why I've been telling you (the reader) all this - in order to get to Richard's story." His fractured narrative promotes us to go beyond what we first read and moves us into a new narrative boundary. Thus, such constant narrative technique increases the readers' expectations. By creating a maze of desire, Auster lures readers deeper into the core of the story.

In Chapter 5, the narrator states:

I was eager to return to the blue notebook [...] ten minutes later, I was in the apartment, sitting at my desk in the room at the end of the hall. I opened the notebook, turned to the page where I had left off on Saturday, and settled down to work. I didn't bother to read over what I had written so far. I just picked up the pen and started to write. (p. 52)

By applying this paragraph, the inner narrator, Sidney jumps in to remind us that it is just a process of composing a story, and to bring us back to the actual writing situation. He is not a character of the novel, but a narrator or writer. By this means, the comments and indicative words make the plots differently discontinuous. And it makes readers understand that the novel is unreliable and it can be overturned by anyone instead of the author.

I opened the notebook, and when I glanced down at the page in front of me, I realized that I was lost, that I didn't know what I was doing anymore. I had put Bowen into the room [...] but once I'd pushed the story in that direction, I had diverged from the original premise of the exercise. My hero was no longer walking the same path that Flitcraft had followed. (p. 96)

The narrator doubts his narrative process, which proposes a kind of self-reflexivity. In this way, the author of Oracle Night makes the reader aware that what they read is actually not real life but instead a representation or fiction. It successfully eliminates the co-existence of several plots and solves the borderline of the intersection of truth and falsity in the story. Sidney, as well as the author, combining the world created in the novel together with his protagonist's fantastic world to make readers feel as if seeing a rapid channel-switching. It makes readers accept the abrupt disconnection and randomness with no preparations. The story of Sidney Orr is connected by his story, and from the story and the inner mysterious elements and atmosphere, it can be concluded that the whole novel is a mystery and all things just happen by chance.

As Brendan Martin says in Paul Auster's Postmodernity, “Auster's postmodern worldview encompasses an overwhelming lack of cognitive certainty, foundational indeterminacy, ontological skepticism, and the open play of story." (Martin, 2008, p. 103) In Oracle Night, stories are not organized around a concrete theme or according to a series of clues. The world we live in is full of possibilities, so when it comes to novels, readers also become more involved in the story than ever before. The story of Sidney Orr is connected by his stories and from the story and the inner mysterious elements and atmosphere, readers can conclude that the whole novel is a mystery and all things just happen by chance. In this way, the author leaves enough room in the novel for the reader to inhabit. And readers thus have more room to figure out which way is more reasonable.

\section{CONCLUSION}

Oracle Night, a triumph for Auster, cements his growing reputation as one of America's most inventive and original writers. And Auster shines as a fabulist and story-teller, putting a high-modernist gloss on noir. He again demonstrates the full extent of his writing skills in this intricate novel. The metafictional structure subverts the traditional narrative structure, breaks up the traditional aesthetic approach and forms a new type of literature.

The creator of Oracle Night breaks the fiction tradition characterized by order and organization of beginning, middle, and end and forms an opened narrative, which is a significant structural feature of metafiction. By challenging the "closed" structure of classical realism, rejecting totalized, single, and determined narratives, the novel advocates the openness of metafictional writing.

Therefore, the challenging conflict is not between chesses in a board game, but between the chess players, the random arrangement and insertion of plots and stories endow the novel with a flavor of openness, hence, inviting or forcing readers to exert their imagination to integrate the pieces into an organic whole.

\section{ACKNOWLEDGMENT}

My deepest thanks are owed to my teacher, Professor Yunhui Zhang for her constructive and insightful guidance and valuable advice on this paper. Special thanks go to my husband, David, who has always been my devout supporter in research. 


\section{REFERENCES}

[1] Varvogli, A. (2001).That is the Book: Paul Auster's Fiction. Liverpool: Liverpool UP.

[2] Aristotle (1997). Poetic. Heath, Malcolm. London: Penguin Books.

[3] Auster, P. (2004). Oracle Night. New York: Henry Holt Co. Ltd.

[4] Auster, P. (1992). The Art of Hunger: Essays, Prefaces, Interviews. New York: Sun \& Moon Press.

[5] Beckson, K. \& A. Ganz. (1983). Literary Terms: A Dictionary. New York: Farrar, Straus and Giroux.

[6] Bertens, H. (1995). The Idea of Postmodern. New York: Routledge.

[7] Martin, B. (2008). Paul Auster's Postmodernity. New York \& London: Routledge.

[8] Creeley, R. (1994). “Austerities-Interpretations of Paul Auster's writings.” The Review of Contemporary Fiction. London: Dalkey Archive Press.

[9] Delaney, S. (1958). A Taste of Honey. New York: Grove Press.

[10] Goffman, E. (1974). Frame Analysis. Boston: Northeastern University Press.

[11] Bloom, H (ed.) (2004). Paul Auster. Philadelphia: Chelsea House Publ.

[12] Shiloh, I. (2002). Paul Auster and Postmodern Quest. New York: Peter Lang Publishing, Inc.

[13] Lodge, D. (1970). The Novelist at the Crossroads. New York: Cornell University Press.

[14] Lodge, D. (1977). The Modes of Modern Writing. New York: Cornell University Press.

[15] Mckee, R. (1997). Story: Substance, Structure, Style and the Principles of Screenwriting. London: Methuen Publishing.

[16] Miller, J. (1998). Reading Narrative. Norman: University of Oklahoma Press.

[17] Spiegel, N. (1971). On Aristotle's Theory of Poetry (Hebrew). Jerusalem: Bialik Institute.

[18] Stuart, S. (2005). The Routledge Companion to Postmodernism. London: Routledge.

[19] Waugh, P. (1984). Metafiction: The Theory and Practice of Self-conscious Fiction. New York: Methuen.

[20] Žižek, S. (1995), Looking Awry. Boston: The MIT Press.

[21] Zhang, Zhongzai. (2006). Selected Readings in Classical Western Critical Theory. Beijing: Foreign Language Teaching and Research Press.

Hui Ni was born in Heze, Shandong, China in 1982. She received her M.A. degree in (English) pedagogy from Bohai University, China in 2009.

She is currently an assistant in the School of foreign languages, Heze University, Heze, China. Her research interests include contrastive teaching and literary criticism. She has published many research papers in domestic magazines. E.g. A Contrastive Study on Images of Woman between Chinese and Western Traditional Cultures(Qufu, Shandong: Modern Chinese, 2011). 